\title{
СПОСОБИ УТВОРЕННЯ ФРАНЦУЗЬКИХ ТОПОНІМІВ, ПОХІДНИХ ВІД АНТРОПОНІМНИХ НАЗВ
}

\section{Пежинська О. М.}

\section{ВСТУП}

Топоніми зазвичай творяться автохтонним населенням певної території. Це дає змогу встановити, що певна територія колись належала іншому народу, аніж тому, що проживає там тепер. Тобто топоніми характеризують територію з погляду тих народів, які колись населяли ту чи іншу місцевість. Як зазначає О.В. Суперанська, 3 50-60-х років XX ст. ономастична лексика розглядається як самостійна система, яка має свій територіально організований набір топооснов, топоформантів, а також правил і способів їх з'єднання між собою ${ }^{1}$.

На відміну від А. Доза, який особливу увагу приділяє семантичній еволюції топонімів, французький лінгвіст Е. Віаль досліджує топоніми за способом номінаціїㄹ․

У межах групи назв, похідних від антропонімів, привертають увагу насамперед ті, що утворені від власних імен осіб, а також похідні від загальних назв осіб (назви племінно-етнічних груп або вихідців з інших місць). Значна кількість відантропонімних топонімів зумовлена передусім тим, що географічні об'єкти зазвичай комусь належали, звідси - географічні назви, утворені від імен власників.

У досліджуваних топонімах відантропонімний фонд представлений доволі повно, оскільки існування багатьох населених пунктів тісно пов'язане 3 діяльністю конкретних осіб, які були власниками об'єктів (землі) або ж проживали на цій території. Творення найменувань місцевостей від антропонімів невипадкове, оскільки з зародженням родоплемінних відносин сформувався і вже глибоко вкоренився в суспільному побуті звичай іменувати роди за іменами старійшин чи родоначальників, що з часом перейшло і на назви їхніх земель.

Водночас лінгвістичний аналіз відантропонімних онімів Франції свідчить, що чимало вживаних тут християнських імен за своїм походженням $\epsilon$ запозиченнями (йдеться про місце їх виникнення). Відантропонімні топоніми мотивуються:

${ }_{1}^{1}$ Суперанская А.В. Что такое топонимика?. Москва : Наука, 1985. С. 108.

${ }^{2}$ Vial E. Les Noms de villes et de villages. Paris : Belin, 1983. 319 p. 
1) іменами власників територій;

2) епонімами (назвами божеств);

3) іменами святих (hagiotoponymes);

4) родоплемінними іменами та назвами різних народів (відетнонімні найменування).

\section{1. Топоніми, утворені від імен власників територій та від назв божеств (відепонімні найменування)}

Римське завоювання не припинило і навіть не загальмувало процесу творення галльських ВН. Навпаки, протягом одного чи двох століть кельтизація Галлії продовжувалася на півдні та на південному сході як протидія іберійській та лігурській мовам. Вплив Риму проявляв себе спочатку виникненням численних галло-римських гібридів, коли до галльського детермінатива додавалася назва одного 3 засновників імперії (Jules César, Auguste) $)^{3}$.

3 метою уникнення омонімів у галльській топонімії використовувалися Augustobona, Augustodunum, Augustonemetum, Augustoritum, Augustobriga, Caesaromagus, Juliobona, які згодом зникли.

Римляни залишили на французьких землях значну кількість топонімів, наприклад, Coutances, Cottance (Loire) < лат. Constantius, похідними від яких є деривати з суф. -acum > Cottenchy (Somme), -anum > Coustaussa $(\text { Aude })^{4}$;

Orléans (Loiret) < від лат. імені Aurelius + суф. - anum $^{5}$;

Grenoble (Isère) < від імені римського імператора Gratianus + грец. polis, ville ${ }^{6}$.

У південно-західній частині Франції почали формуватися топоніми на позначення сіл з кінцевими -ac або -an, які витісняли суфікс -ius: Biran, від Birius, Pessan (Gers) від Peccius ${ }^{7}$.

Чимало топонімних утворень на території Франції залишили вестготи (згуртувались як окреме плем'я у 268 році, коли вторглися на Балканський півострів). Це переважно оніми із суфіксом -ing у тулузькому регіоні, центрі вестготського королівства. Відбулася зміна цього суфікса на -ens у тулузькому регіоні та на -enx - у Ландах. Суфікс -eng/-ing продовжував функціонувати у південно-західній частині

\footnotetext{
${ }^{3}$ Dauzat A. Les noms de lieux. Origine et evolution. Paris : Librairie delagrave, 1926. 264 p.

Dauzat A. Dictionnaire etymologique des noms de lieux en France. Ch. Rostaing. Paris : Larousse. Librairie Guenegaud, 1963. P. 215.

${ }^{5}$ Ibid. P. 510.

${ }^{6}$ Ibid. P. 332.

${ }^{7}$ Ibid.. P. 526.
} 
країни: Escatalens (T.-et-G.) < Scatal-ing, Guitalens (Tarn) <герм. ім'я Wital + суф. -ing, Ratayrens < герм. ім'я Rathari-ing та інші ${ }^{8}$.

Римська антропонімія також представлена іменами великих землевласників та монархів. Здебільшого це були складні галлолатинські власні назви, багато 3 яких 3 часом вийшло 3 ужитку. Численні назви утворювалися двома способами: галльське ім'я + латинський суфікс або від особових латинських імен, якими часто називали себе галли. Зокрема, латинські імена часто вибирали для себе шановані люди.

Наприклад, галло-римлянин Alaudius (< alauda, alouette) мав ферму Villa Alaudii, la Ferme d'Alaudius. Ця назва позначала не тільки помешкання господаря, а й будинки селян на цій території, що становили зародок майбутнього села. Відповідно, словосполучення Villa Alaudii втратило лексему villa, в результаті чого утворився топонім Allauch (BdR). Таким же способом сформовані інші топоніми: ферма Блавіуса (Blavius) > (Villa) Blavia > Blaye (Gironde); Alexandri (Villa) > Lessandre > Le Cendre (PdD); Cornuti (Villa) > Cornut > CorpsNuds (I \& V) $)^{9}$.

Ще одним способом утворення назви власності є додавання суфікса до імені власника. Назви, утворені від антропоніма та суфікса, є доволі поширеними. Найуживаніший суфікс -acum або -іасит присутній у 5\% французьких топонімів 3 різними фонетичними варіантами, залежно від регіону (рис. 1).

Варіант -acum, який є латинізованим кельтським суфіксом -aco, почав розвиватися на території Франції після римського завоювання. Таким чином, власність Амбаріуса (d'Ambarrius) називалася Ambarriacum, звідки утворилася ВН Ambérieu (Ain), Ambérieux (Rhône) $^{10}$, відповідно Andeliacum $>$ Les Andelys (Eure) ${ }^{11}$.

Назви з суфіксом -асит поширилися по всій території Франції, крім південного-сходу. Ці топоніми особливо поширювалися в регіонах, привабливих для римських землевласників (поблизу міст, шляхів сполучення тощо). Серед галльських антропонімів доволі продуктивною була ВН Brennus > Brenn-acum > Brenat (Puy-de-Dôme), Bernac (Char.), Brenac (Aude) та Bern-iacum > Berny (Somme), Bargny

${ }^{8}$ Dauzat A. Dictionnaire etymologique des noms de lieux en France. Ch. Rostaing. Paris : Larousse. Librairie Guenegaud, 1963. P. 557.

${ }^{9}$ Vial E. Les Noms de villes et de villages. Paris : Belin, 1983. 319 p.

${ }^{10}$ Dauzat A. Les noms de lieux. Origine et evolution. Paris : Librairie delagrave, 1926. P. 13.

${ }^{11}$ Ibid. P. 17. 
$(\text { Oise })^{12}$, проте переважання латинських форм прискорило занепад галльських антропонімів ${ }^{13}$. Декілька найпоширеніших типів топонімів, утворених від лат. антропоніма з суф. Асит, та їх основні варіантами наведемо у таблиці 1.

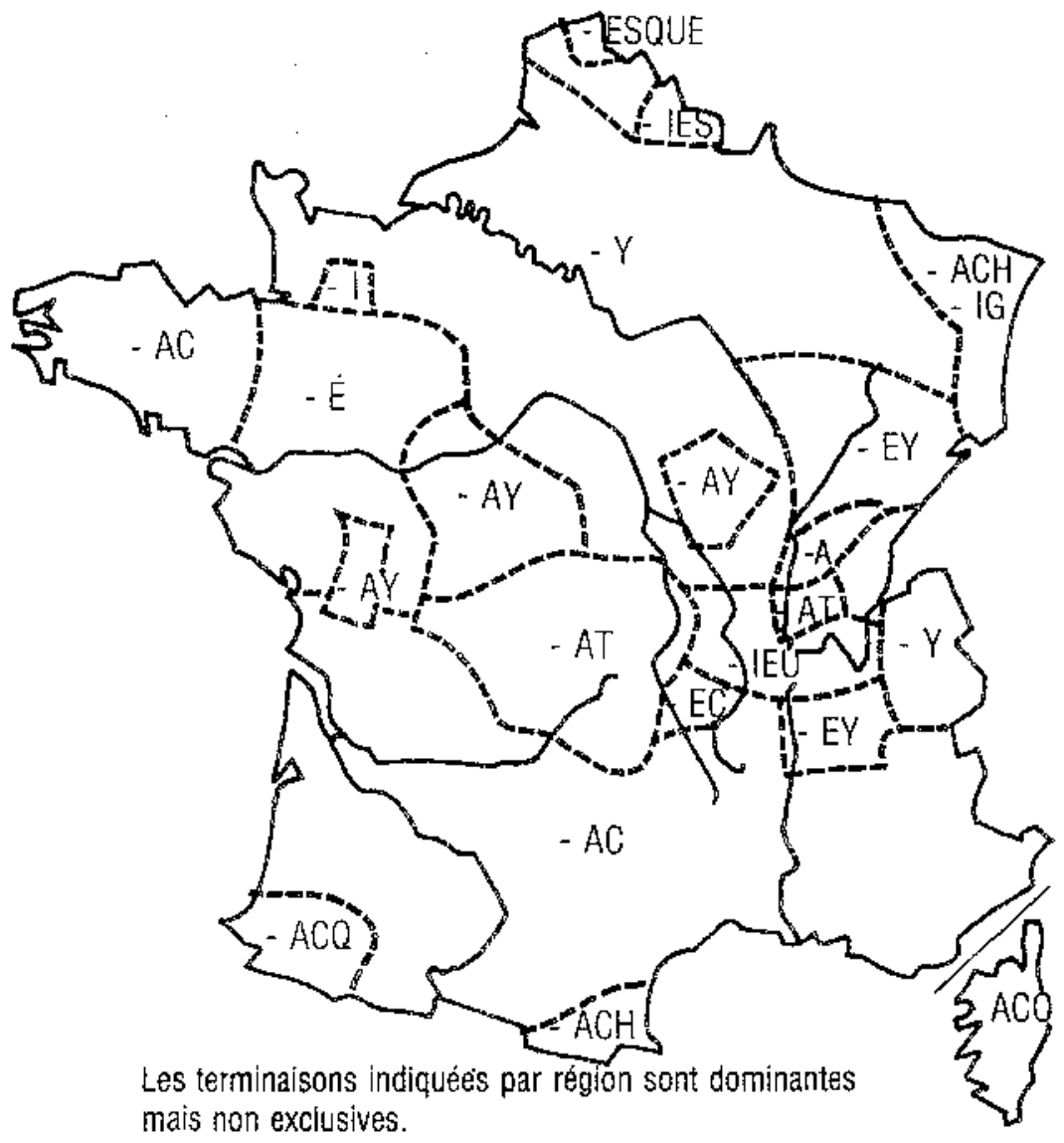

Terminaisons issues de - (i) acum

Рис. 1. Топоніми, утворені від імені власника та суфікса -(i)acum відповідно до регіонів

${ }^{12}$ Dauzat A. Dictionnaire etymologique des noms de lieux en France. Ch. Rostaing. Paris : Larousse. Librairie Guenegaud, 1963. P. 54.

${ }_{13}$ Dauzat A. Dictionnaire etymologique des noms de lieux en France. Ch. Rostaing. Paris : Larousse. Librairie Guenegaud, 1963. 738 p. P. 115. 
Варіантні реалізації топонімів із суфіксом -асит

\begin{tabular}{|c|c|c|c|}
\hline $\begin{array}{c}\text { латинський } \\
\text { антропонім + } \\
\text { суф.-асит }\end{array}$ & $\begin{array}{c}\text { провансальська } \\
\text { мова } \\
\text { (langue d'oc) }\end{array}$ & $\begin{array}{c}\text { франко- } \\
\text { провансальська } \\
\text { (franco- } \\
\text { provençales) }\end{array}$ & $\begin{array}{c}\text { мова } \\
\text { північних } \\
\text { районів } \\
\text { Франції } \\
\text { (langue d'oïl) }\end{array}$ \\
\hline Albiacum & $\begin{array}{l}\text { Albiac, Aubiac, } \\
\text { Aujac, Aubiat }\end{array}$ & Albieux & Auby, Augy \\
\hline Albiniacum & $\begin{array}{l}\text { Albignac, } \\
\text { Aubignac, } \\
\text { Aubignat }\end{array}$ & $\begin{array}{l}\text { Arbignieu, } \\
\text { Arbigny }\end{array}$ & $\begin{array}{l}\text { Aubigné, } \\
\text { Aubigny, } \\
\text { Herbigny }\end{array}$ \\
\hline Avitacum & Aydat & $\begin{array}{l}\text { Avitiacum, } \\
\text { Avezac, Auzat, } \\
\text { Azat }\end{array}$ & $\begin{array}{l}\text { Avezé, Azay, } \\
\text { Azé, Azy }\end{array}$ \\
\hline Campaniacum & $\begin{array}{l}\text { Campagna, } \\
\text { Champagnac, } \\
\text { Champagnat }\end{array}$ & $\begin{array}{l}\text { Champagny, } \\
\text { Champagney }\end{array}$ & $\begin{array}{l}\text { Champagné, } \\
\text { Champigné, } \\
\text { Champigny }\end{array}$ \\
\hline $\begin{array}{l}\text { Flaviacum } \\
\text { (який } \\
\text { найбільше } \\
\text { піддається } \\
\text { змінам) }\end{array}$ & $\begin{array}{l}\text { Flaviac, } \\
\text { Flaugeac, Fléac, } \\
\text { Flat }\end{array}$ & $\begin{array}{l}\text { Flagey, Flagy, } \\
\text { Flavy, Fyé, } \\
\text { Flée, Fly, та ін }\end{array}$ & \\
\hline Gaudiacum & Gajac & & Joué, Jouy \\
\hline Victoriacum & Vitrac & & $\begin{array}{l}\text { Vitray, Vitré } \\
\text { Vitry }\end{array}$ \\
\hline Veriacum & & Virieu & Viré, Viry \\
\hline
\end{tabular}

Суфікс -acum отримав форму - $a c$ (на півдні) > -at, -as на півночі та в інших регіонах. На заході Франції використовувався суфікс -ay, -é, решту регіони розрізняють -iacum $\rightarrow y$ та -acum $\rightarrow a y$,-é. У частині Бретані (Bretagne) кінцевою словоформою стала - $a c$. Регіони, які були пізніше германізовані, змінили закінчення -асит > -ac, наприклад: Dornac (Dord) < від галл. імені Luturnos ${ }^{14}$; -iacum > ic: Juillac (Corr., Gers, Gir.) < від лат імені Juliacum ${ }^{15}$.

${ }^{14}$ Dauzat A. Dictionnaire etymologique des noms de lieux en France. Ch. Rostaing. Paris : Larousse. Librairie Guenegaud, 1963. P. 251.

${ }^{15}$ Ibid. P. 371. 
Згадку про язичницьку релігію становили епоніми, утворені

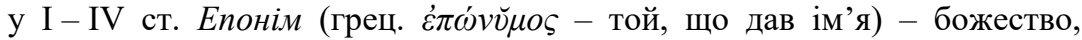
видатна людина або герой, на честь якого іменований певний географічний об'єкт (місто, ріка, гора та ін.), наприклад, назви Beaune (Allier, H.-Vienne), Baulne (Aisne, S.-et-O.), Beaulne < галл. Belena (прикметник ж. роду) < Belenos (галльський епонім) ${ }^{16}$; галльська богиня Belisama увіковічнена у назвах Bellême (Orne), Blesmes (Aisne), Blismes (Nièvre) ${ }^{17}$.

Від Bormo, або Borvo (божество теплих вод) утворилися топоніми Boulbon (B.-du-R.), Bourbon (S.-et-L.), Bourbonne (H.-Marne) ${ }^{18}$.

Найпоширенішим у топонімії є ім'я бога Меркурія (лат. Mercurius), найчастіше варіант Mercŏriu(m), Mercŏre > Mercoeur, Mercus, Mercuer, Mercuès (в похідних Mercurol, Mercuriol) ${ }^{19}$.

Ім'я лат. богині Minerva трансформоване у Minerve, Ménerbes, Ménesble (Hér., С.-d'Or); римської богині Diana > Dienne(s) (Cant., Nièvre); римської богині Latona > Losne, Lannes (H.-Marne, C.-d'Or). Імена інших богів задіяні тільки у складених назвах: Jupiter - у назвах Fanjeaux (Aude) < fanum Jovis, temple de Jupiter ${ }^{20}$. Mars - у назвах Famars (Somme) > fanum Martis, temple de Mars, Templemars, Talmas (північ) $<$ templum, temple + Mars $^{21}$.

Жодне християнське топонімне утворення не перейшло у римську епоху. Деякі складові елементи релігії, коріння яких сягає епохи неоліту й освячене традицією, зберігалися дуже довго, їх сліди проглядалися навіть в середньовічному християнстві. Це - реліктові форми тотемізму, культ мертвих і предків, Великої Богині МатеріЗемлі, вогню, солярні (сонячні) культи. Написи й зображення, свідчення римських письменників дають інформацію про чималу кількість давніх кельтських богів. Більшість з них - місцеві та племінні боги-заступники; окремі божества тощо. Галли встановлювали численні вівтарі на честь богів, яким вони поклонялися. Особливо шанованою була богиня Belisama, що уподібнювалася богині Minerve, ім'я якої лежить в основі топонімних назв Bellême (Orne), Blesmes (Aisne), Blismes (Nièvre) ${ }^{22}$. Бог Lug відомий тим, що його іменем

${ }^{16}$ Dauzat A. Les noms de lieux. Origine et evolution. Paris : Librairie delagrave, 1926. P. 59.

${ }^{17}$ Ibid. P. 48.

${ }^{18}$ Ibid. P. 103.

${ }^{19}$ Dauzat A. Dictionnaire etymologique des noms de lieux en France. Ch. Rostaing.

Paris : Larousse. Librairie Guenegaud, 1963. P. 434.

${ }^{20}$ Ibid. P. 282.

${ }^{21}$ Ibid. P. 668.

${ }^{22}$ Brunhes J. Geographie humaine de la France. Paris, 1921. T. I. 299 p. 
назвали столицю Галлї̈ Lugdunum > Lyon, а також інші об'єкти, наприклад, Laon (Aisne), Lion-sur-Mer (Calvados), Loudon (Sarthe) ${ }^{23}$.

\section{2. Топоніми, утворені від імен святих}

У V столітті починає домінувати християнство і вже на початку II тис. на більшій частині території Західної Свропи воно стає найпоширенішою релігією. Церквам дають імена святих. Папа Sixte III у 431 р. присвятив собору ім'я Діви Mapiï (Sainte-Marie-Majeure). Звичною стала традиція, коли ім'я святого та назва села однаково слугують для позначення місцевості - iї дотримувались протягом декількох століть.

Привертає увагу назва місцевості Sainte-Mère-église. Згідно 3 позицією французького лінгвіста Рене Лепллі (René Lepelley) йдеться не про початкову назву населеного пункту, а про неправильне відтворення латинської назви, якою упродовж віків називали церкву: Sanctae Mariae Ecclesia, "l'église de sainte Marie" - «церква святої Mapiï», >Sainte Mariglise > Sainte-Mar-Iglise та сучасною французькою мовою Sainte-Mère-église ${ }^{24}$

У середині X ст. місцевість Saint-Martin-d'Abbat (Loiret) почала називатися спрощено - Abet. У XIV ст. документ латиною дає назву місту - S. Martinus de Abbeto. У 912 р. топонім Saint-Nicolas-de-Port (департамент Meurth-et-Moselle) в народі спростився до Port ${ }^{25}$. Топонім Saint-Venant (Pas-de-Calais) $є$ стародавньою назвою Saint Venant de Papigghem, елемент якої випав згодом.

Стародавні назви поступово зникають, i це породжує міфічні тлумачення. Наприклад, Saint-Julien-du Sault (Yonne) отримало зредуковану форму Le Sault < salix, saule (верба). Приєднана до Saint Julien, лексема Sault не була зрозумілою, їі плутали з загальною назвою saut. Для спростування різночитання наведемо легенду: кінь одного святого, рятуючись від ворога, скочив з високого горба і стрибнув у яму, звідкіля почало бити джерело. Начебто, якщо покласти руку на камінь в глибині водоймища, то можна відчути форму підкови ${ }^{26}$. У цьому разі народна етимологія полягає в неправильному тлумаченні слів, зумовленому нерозумінням їх, що інколи призводить до змін у їхній структурі.

${ }^{23}$ Coste J. Dictionnaire des noms propres : Toponymes et patronymes de France. Paris : Armand Colin, 2006. 700 p.

${ }^{24}$ Dauzat A. Les noms de lieux. Origine et evolution. Paris : Librairie delagrave, 1926. 264 p.

${ }^{25}$ Dauzat A. Dictionnaire etymologique des noms de lieux en France. Ch. Rostaing. Paris : Larousse. Librairie Guenegaud, 1963. P. 232.

${ }^{26}$ Ibid. 
Перші топоніми, утворені від назв святих (hagiotoponymes від грецького hagios, saint, святий), зафіксовані не лише у формах SaintPierre та Saint-Paul. Культ святих припадає на каролінгський період (VIII-X ст. (751-987) - саме 3 того часу населені пункти беруть назву святого заступника своєї церкви. Перші позначення починалися 3 елемента dominus > domnus >dom, don, dam, яким називали Господа i який означав у цей період «святий». Особливо це стосується германізованих регіонів, переважно на сході (Вогези), найвідомішим прикладом є назва місцевості Domrémy-la-Pucelle - рідне місто Жанни д’Арк. Елементи dom, don, dam найчастіше поєднані з назвами Pierre, Martin ou Marie:

Dampierre (Cher, Côte-d'Or, Eure-et-Loir, Indre, Loiret, Nièvre),

Dommartin (Ain, Doubs, Nièvre, Somme),

Dannemarie (Doubs, Haut-Rhin).

У domnum, $o>a$, як у Dammartin < D. Martinum, Dampierre < D. Petrum, Damphal (Haute-Marne) $<$ D. Fidolum; $o>e$ у назвах Demuin (Somme), < D. Audoenum, o > ou y Doulevant (Haute-Marne) < D. Lupentium та Douriez. (Pas-de-Calais) < D. Ricarium (D. Reiher y 1137 p. $)^{27}$.

Група $m n$, що утворилася в результаті синкопи голосних, ввійшла до складу топонімів з початковими Dom-, Dam-. Прогресивна асиміляція зафіксована у BH Donnement (Aube), від D. Amandum, Donnemarie (Haute-Marne, Seine-et-Marne), від D. Maria ${ }^{28}$.

Елементи dom, don, dam знаходимо найчастіше із назвами Pierre, Martin ou Marie: Dampierre (Cher, Côte-d'Or, Eure-et-Loir, Indre, Loiret, Nièvre), Dompierre (Côte-d'Or, Nièvre), Dammartin (Jura, Seine-et-Marne), Dommartin (Ain, Doubs, Nièvre, Somme), Dammarie (Eure-et-Loir, Seineet-Marne), Dannemarie (Doubs, Haut-Rhin), Donnemarie (Haute-Marne, Seine-et-Marne).

У domnum, $o>a$, як у Dammartin < D. Martinum, Dampierre < D. Petrum, Damphal (Haute-Marne) $<$ D. Fidolum; $o>e$ у назвах Demuin (Somme), < D. Audoenum, o > ou y Doulevant (Haute-Marne) < D. Lupentium та Douriez (Pas-de-Calais) $<$ D. Ricarium (D. Reiher y 1137p.).

Група $m n \in$ результатом синкопи голосних, звідки топоніми 3 початковими Dom-, Dam-.

27 Пежинська O.M. Компонент Saint та його роль в утворенні складних топонімних назв у старофранцузькій мові. Вісник Львівського університету : серія «Іноземні мови». 2009. Вип. 16. С. 84-92.

${ }^{28}$ Lejeune S. La religion dans la toponymie. Festival International de Geographie 2002 Saint-Die-des-Vosges «Les espaces et les lieux du religieux». URL: http://fig-st-die.education.fr/actes/actes_2002/index.htm 
Проте регресивна асиміляція на $n$ зафіксована у ВН Donnement (Aube), від D. Amandum, Donnemain (Eure-et-Loir), від D. Emanum, Dannevoux (Meuse), від D. Ipolitum, Dannemarie (Doubs, Seine-et-Oise), Donnemarie (Haute-Marne, Seine-et-Marne), від D. Maria.

У деяких випадках лексема dominus позначала не лише святого, а й простого вірянина. Наприклад, топонім Damparis (Jura) зберігає пам'ять про деякого Paris, засновника монастиря, біля якого зародилося село ${ }^{29}$.

У феодальний період ця система позначень набула значного поширення. На початку XX ст. уже 5000 поселень (із загальної кількості 36 497) названі на честь святих. Цей феномен особливо стосується Центрального Масиву. У департаментах Ардеш (l'Ardèche) (29\% назв комун) та Дордонь (Dordogne) (27\%) налічується найбільша кількість назв, утворених від імен святих. У каролінзький період Sanctus змінилося на dominus, який втратив значення «святий» спочатку у нових утвореннях, а з часом - майже у всіх назвах.

Термін sanctus почав використовуватися як збірний іменник, про що свідчать старовинні кристалізації Saints та Sains: Saints-en Puisaye названий у VI ст. ad Sanctos. Чимало форм 3 компонентом dominus спостерігається у франко-провансальському мовленні. Найпоширеніший на сході, цей епітет вживається здебільшого перед іменами Pierre, Martin (євангеліст Галліі) та Marie (Діва Марія) як доказ того, що розвиток назв святих починається саме з цих імен, зокрема, культ Діви (la Vierge) почав розвиватися після XIII ст., коли вже були закладені основи топонімії.

Численними є варіантні реалізації Dompierre та Dampierre; Dommartin та Dammartin. Максимальна кількість їх налічується в Лотарингіï (Lorraine): Dombasle, Danjoutin, Damblain, Dampaire, Doulevent, Donjevin.

Domina Maria, Sainte Marie зазнало трансформації, ставши в результаті Dammarie (Eure-et-Loir, Seine-et-Marne), Dannemarie (Doubs, Yvelines), Donnemarie (Haute-Marne, Seine-et-Marne) ${ }^{30}$.

Топоніми Domjean (Manche), Domfront (Orne), Domalain (dom Alain, Ille-et-Vilaine) є винятками та трапляються тільки на півночі країни. На сході кількість топонімів 3 компонентом dom значно більша. У центральній частині та на заході dom не залишив жодного сліду у топонімії. Такі утворення функціонують на півночі (Сентонж, (Saintonge), Ангумуа (Angoûmois), Альє (Allier), Сона і Луара

${ }^{29}$ Dauzat A. Les noms de lieux. Origine et evolution. Paris : Librairie delagrave, 1926. P. 233.

${ }^{30}$ Ibid. 
(Sâone-et-Loire) $^{31}$. Водночас у назві місцевості Damprichard (Doubs) Dominus є феодальним титулом, а не церковним ${ }^{32}$.

Після 1000 р. лексема dominus перед назвами святих перестає вживатися, трапляються лише окремі випадки на сході Франції, наприклад, вже згадуваний топонім Damparis (dominus Patricius) утворився пізніше, а саме у 1150 році. У старовинних текстових згадках налічується 752 назви місцевостей із компонентом dominus ${ }^{33}$.

У XI-XIII ст. на сході Франції топоніми 3 елементом Saint позначали місцевість за назвою святого заступника церкви. Раніше цей термін використовувався для позначення храмів, де зберігалися мощі святих. Saints-літературна та Sains-народна форми фіксуються у різних департаментах на півночі Луари. Компонент saint спочатку символізував церкву, а вже згодом за метонімічним принципом - ii землі та церковну парафію: в картуляріях часто записували, наприклад, "sur les terres de Saint Julien (de Bansat)"34.

У лексемі sanctum вокалізація звука $i$ продукує через метатезу французьке saint. Палатальне $a$ іноді зникає. Saint змінюється на san(t), наприклад, Saint-Beury (Gôte-d'Or) записувалося у XIII ст. як Senburri, Sanburré, a BH Saint-Chéron - як Sancheron. Це ж стосується назви Sancerre (Cher), що представляє святого S. Satyrumm; Sancergues (Cher), S. Cyriaum, Samans (Ain), S. Marnes.

Фонетичний аспект топонімів з компонентом saint спостерігається в особливих випадках, наприклад, у лат. sanctum > sanch, де ch аглютинується перед назвами святих, в яких початковою є голосний звук. Таким чином, Sanctum Amandum > Sanch Amand > San Chamand > Saint-Chamand (Cantal, Corrèze, Puy-de-Dôme), а також Saint-Chaptes (Gard) d'Agatha; Saint-Chamarand (Lot), d'Amarandum; Saint-Chamond (Loire), d'Annemundum; Saint-Chinian (Hérault) та Saint-Chignes (Lot), d'Anianum; Saint-Chamassy (Dordogne), d'Eumachium; Saint-Chély (Aveyron, Lozère), d'Hilarum. Для топонімів, похідних від імен святих, притаманне випадіння початкової приголосної:

Saint-Aurin (Somme) < Saint-Taurin < Taurinum; Saint-Yorre (Allier) < греко-лат. Georgius. Ім'я Georgius фіксується у назвах St-Geoirs (Isère), St-Joire (Meuse), St-Jurs (B.-Alpes), які є народними та Saint-Georges (Char., Gers та ін.) - класична форма. Трапляються випадки, коли

${ }^{31}$ Dauzat A. Les noms de lieux. Origine et evolution. Paris : Librairie delagrave, 1926. P. 151 .

${ }^{32}$ Fabre P. Noms de lieux du Languedoc. Paris : Bonneton, 1995. 243 p.

${ }^{33}$ Dauzat A. Les noms de lieux. Origine et evolution. Paris : Librairie delagrave, 1926. P. 151.

${ }^{34}$ Ibid. P. 160. 
топоніми-дублети функціонують в одному регіоні, наприклад, St-Jores та Saint-Georges-de-Bohon(Manche) та інші ${ }^{35}$.

Простежується оформлення жіночих імен, від яких утворюються ВН: лат. Scubiculus у Sainte-Escobille (Seine-et-Oise) ${ }^{36}$.

Чимало дублетних форм топонімів утворено від народної форми: герм. Math-hard > Médard, наприклад, St-Marc, St-Mard, St-Mars, St-Mézard (Aisne, Somme, Marne, Eure) / Saint-Médard (Creuse, Indre, Lot, Mos. та інші). Зафіксовані фонетичні омоніми (омофони) SaintMars / Cinq-Mars ${ }^{37}$.

Германський суфікс -hari > -ier, пізніше -er, у назвах Saint-Léger (Alpes-Mar., Char., Manche та ін.), Saint-Lager (Rhône) < франкопровансальської форми герм. Leudgari. Книжні форми вживаються із суфіксом -aire, наприклад, Saint-Liguaire (D.-Sèvres) ${ }^{38}$.

Важливу роль у топонімії відіграє субституція - заміщення однієї назви іншою, яка може бути спонтанною, коли топонім витісняє стародавню назву, та систематичною, коли заміна встановлена й узгоджена з органами влади. Згідно з А. Доза, спонтанна субституція була доволі поширеною в період Середньовіччя. Наприклад: SaintGermain (раніше називалося Lida, Ledia латинською) вживається 31124 року; Saint-Cloud (раніше Nogent) датується 1222 p. SaintMichel-XIII ст.; Saint-Yon - 1186 р.; Saint-Malo - XII ст.; на півдні Saint-Jean - 1154 р. та Saint-Jean (de Luz) - 1186 p.; Saint-Denis, раніше Catulliacum, вважається найдавнішим топонімом.

Зміна початкової стародавньої назви відбувається поступово: назва святого saint передує початковій назві місцевості, яка відходить, наприклад, Saint-Sulpice-de-Favières (S.-et-O.) раніше називалося лише Favières $^{39}$. Іноді цей процес є складнішим: Sainte-Geneviève-des-Bois (Loiret, S.-et-O.) (S.Genovefa de nemore, 1209), яке мало раніше назву Séguigny, позначення із загальною назвою bois, приєднується як прізвище до назви святого.

Траплялося, що протягом століть святий заступник церкви змінювався: Saint Julien був першим покровителем комуни Банса (Bansat) (Puy-de-Dôme), згодом saint Caprais замінив його; монастир, збудований у VI ст. у Saint-Hilaire, було названо на честь Saint-Avold, після його відбудови у 765 р. назву змінили на Saint Nabor ${ }^{40}$.

${ }^{35}$ Dauzat A. Dictionnaire etymologique des noms de lieux en France. Ch. Rostaing. Paris : Larousse. Librairie Guenegaud, 1963. P. 600-601.

${ }^{36}$ Ibid. P. 634.

${ }^{37}$ Ibid. P. 613.

${ }^{38}$ Ibid. P. 609.

${ }^{39}$ Ibid. P. 631.

${ }^{40}$ Ibid. P. 619. 
Назви святих (hagiotoponymes) за походженням $є$ чернецькими (monacale), наприклад, назва Saint-Flour (1002 р.) утворилася поблизу монастиря, біля могили святого Flour ${ }^{41}$.

Складні назви, елементи яких подеколи неможливо розпізнати, часто стають об'єктом спотворення, і причини цього виявити важко. Інколи здається, що орфографія шкодить, а фонетично вони відповідають нормам. Ми виявили такі приклади нівелювання місцевого культу святого:

Sainte Araille $\rightarrow$ Sentaraille (Ariège) та Xaintrailles (Lot-et-Garonne); Saint Cergue $\rightarrow$ Sancergue (Cher); Sainte Gabelle $\rightarrow$ Cintegabelle (HauteGaronne); Saint Nary $\rightarrow$ Sanary (Var); інколи назва святого зливається 3 додатком, тому іiі важко розпізнати, лише старовинні тексти дають змогу віднайти іï, наприклад, Saint Père à ville під назвою Saint-Péraville (Nièvre) Saint Père a vi (ad vicum), Saint Péravy (Loiret). Інші назви 3 початковим sin (sain-, cein-, та інші) утворюються в результаті скорочення топоніма: топоніми Saint-Eny та Saint-Cy представлені стародавніми назвами Centeny та Saincy ${ }^{42}$.

Низка інших топонімів зв'язку з іменами святих не має, хоч елемент Saint у них присутній: наприклад, Sainte-Engrace (PyrénéesAtlantiques) є не чим іншим, як Grâce de Dieu (милість Бога), SainteVertu (Yonne), який раніше називався Saintes Vertus, Saint-Ange (Eure-et-Loir, Seine-et-Marne), Saint-Angeau (Charente), Saint-Angel (Allier, Corrèze, Puy-de-Dôme). Деякі назви належать до священних місць: Saint-Champ (Ain), Saint-Mont (Gers), Saint-Puy (Gers), SainteTerre (Gironde) ${ }^{43}$. Всі ці орфографічні варіанти є проявом живого мовлення, тобто записувалися так, як говорилося. Початкове "sain-" може свідчити також про присутність у назві імені святого: завдяки народній етимології таким способом утворилися топоніми Saint-Cy (Nièvre) > Saincy (1357) та Saint-Igny-de-Roche (Saône-et-Loire) > Santigny.

Деякі населені пункти названі в честь місцевих святих, наприклад, бретонських (saint Cast, Guénolé, Jacut, Renan та інші) та лотаринзьких (Basle, Evre, Nabor та інші). Підтвердження цього - карти назв святих у «Географічному словнику Франції» П. Жоан (Dictionnaire géographique de la France de P. Joanne). Крім цього, Ж. Лота (J. Loth), дослідивши назви бретонських святих, констатував, що ці топоніми загалом $є$

${ }^{41}$ Vial E. Les Noms de villes et de villages. Paris : Belin, 1983. P. 161.

42 Dauzat A. Dictionnaire etymologique des noms de lieux en France. Ch. Rostaing. Paris : Larousse. Librairie Guenegaud, 1963. P. 392.

${ }^{43}$ Vial E. Les Noms de villes et de villages. Paris : Belin, 1983. P. 234. 
національними. Такі утворення хронологічно відповідають складним назвам із компонентом Dom- у мові північних районів Франції ${ }^{44}$.

\section{3. Географічне поширення топонімів із релігійними компонентами “dominus" та "saint" та відетнонімні найменування}

Очевидним фактом $\epsilon$ те, що великі зрушення середніх віків змінювали життя у сільській місцевості. Без сумніву, саме католицька релігія вплинула на утворення значної кількості топонімів, підтвердженням цього $є$ топонім Saint Martin (перший топонім, утворений від імені святого у Франції).

Найпоширеніші назви Saint-Jean та Saint-Martin зафіксовані у праці французького географа Жана Брюна, (“Géographie humaine de la France”), де дається розподіл назв за густотою називання місцевостей у французьких департаментах. BH Saint-Jean на карті найпоширеніші на південному сході Франції, тоді як топоніми Saint-Martin - у іï західній частині ${ }^{45}$.

По всій території Франції найбільше таких топонімів: saint Martin на честь єпископа Typa (Tours) у IV ст. (238 комун згідно з П. Жоан та 242 - у теперішній час), St-Jean (171 комуна, 180 зараз), St-Pierre - на честь першого папи (162 комуни та 163 зараз), St-Germain (127 комун та 130 зараз) та St-Laurent (99).

Назв 3 компонентом saintes у множині дуже мало (у тому числі sainte Marie), найпоширенішою є назва Sainte Colombe (28 комун). Існує значна кількість топонімів за назвами місцевих святих:

Кількість топонімів, утворених від назв святих, надзвичайно велика, до того ж усі вони дуже різні. "Dictionnaire des communes" позначає в загальному 36497 населених пунктів, приблизно 4600 назв, початковим елементом яких є Saint, Sainte, San(t), Santa; у відсотковому співвідношенні це майже $12,5 \%$ від всієї кількості топонімів. Налічується 40 назв Saint-Sauveur, Saint-Salvadou (Aveyron) та SaintSalvadour (Corrèze). Ці назви походять від лат. Salvator > Sauveur (Спаситель) ${ }^{46}$. Доволі поширеною по всій території Франції є власна назва Sainte-Croix є (26 топонімів).

У назвах місцевостей переважно зберігаються народна та писемна форми. Вплив церковної латини сприяв поширенню літературного написання по всій території. 3 іншого боку, багато назв святих були повністю забуті, як імена, що даються при хрещені (nom de baptême),

${ }^{44}$ Dauzat A. Les noms de lieux. Origine et evolution. Paris : Librairie delagrave, 1926. P. 164.

${ }^{45}$ Brunhes J. Geographie humaine de la France. Paris, 1921. T. I. P. 299.

${ }^{46}$ Vial E. Les Noms de villes et de villages. Paris : Belin, 1983. P. 234. 
водночас культ їх слабшав, наприклад: Saint-Yrieix, Saint-Héraye (Aredius); Saint-Bérain, Saint-Bérin, Saint-Blin; Saint-Bois, Saint-Bueil, Saint-Beauzire, Saint-Bauzile та Saint-Baudille (Baudilius); Saint-Chéron (Caraunus) ${ }^{47}$.

У місцевих діалектах назви святих, як і інші слова, були під впливом регіональної фонетики, тому у різних частинах Франції ВН певною мірою різняться між собою.

А. Льоньон наводить приклад двох назв святих - Abdon та Sennen, які об'єдналися в топонімі Dandesigny, та деякі випадки змін жіночого роду через злиття та трансформацію: Sainte-Feyre - від назви святого Symphorien, Sainte-Canne (Gers) - від святого Candidus, Sainte-Olive від святого Illidius, Sainte-Ramée - від святого Remigius та інші ${ }^{48}$. Такі зміни почали відбуватися, коли народна форма, кристалізована в топонімі, переставала бути зрозумілою.

У VIII-IX ст. назви багатьох населених пунктів містили елемент dominus - святий, особливо на сході Франції. А. Доза виявив 752 топоніми із компонентом dominus.

У XI-XIII ст. по всій території Франції набув поширення елемент saint, дещо пізніше на Сході, де в топонімах ще зберігався елемент dominus. Майже в кожному разі відбувалася спонтанна субституція, заміщення назв святих, які прийшли на зміну початковим стародавнім назвам.

Найважливішими особливостями топонімів із компонентом saint $€$

1) різномірне географічне поширення їх, тобто деякі назви святих трапляються по всій території Франції (Saint-Martin, Saint-Jean, SaintPierre, Saint-Germain) - за спостереженням Поля Жоан ${ }^{49}$;

2) різноманітність діалектних форм із використанням одного й того ж імені святого (вище вказана їх кількість), що свідчить про розвиток культу святих у феодальний період - за висновком Ж. Брюн ${ }^{50}$.

Упродовж віків кожний етнос, що заселяв Францію, залишив свій слід в ономастичному просторі. 3 III ст. на півдні, південному сході та майже по всій території Галлії назва племені могла називати його головне місто, поступово витісняючи початкову назву міста. Таким чином, особливий інтерес для дослідників становлять відбиті у

${ }^{47}$ Dauzat A. Les noms de lieux. Origine et evolution. Paris : Librairie delagrave, 1926. P. 165.

${ }^{48}$ Longnon A. Les noms de lieu de la France : leur origine, leur signification. Paris : Language, Arts \& Disciplines, 1973. 831 p.

${ }_{49}$ Joanne P. Dictionnaire geographique et administratif de la France et de ses colonies. Paris : Librairie Hachette, 1890-1905. URL: http://gallica.bnf.fr/ark:/12148/bpt6k73390r/ f671.image.r

${ }^{50}$ Brunhes J. Geographie humaine de la France. Paris, 1921. T. I. 299 p. 
топонімії родоплемінні імена та назви різних народів. Етноніми, так звані civitates, як терміни для позначення будь-якого етносу або етнічної спільності (роду, племені, племінного союзу, народу, народності, нації) вказують на міграції населення в минулому. Чотири племені утворили свої міста: перигорське (périgourdine), де проживало галльське населення Pétrocores < лат. Petrocorii, овернське (auvergnate), населене Auvernes; вандійське (vendéenne) та пуатвійське (poitevine), яке населяли галли Pictaves. Два останніх міста займали територію площею, як чотири департаменти Франції. Кожне місто мало свою столицю і свого короля. А. Льоньон визначив 60 таких головних міст. Це переважно важливі агломерації, особливо на південному сході країни, від яких утворилося 38 сучасних міст.

Кожне плем'я мало свою територію i жило великими угрупованнями, які римляни називали civitas [kiwitas] (у множині civitates) - латинський апелятив жіночого роду, утворений від civis, “citoyen” - громадянин. Цей термін має кілька значень: громадянство, права громадян та міста, сукупність громадян, які формують місто чи державу, територія, яку займає суспільство. 3 лінгвістичного погляду утворення нових назв пояснюється легко. У народній латині родовий відмінок поступово замінюється конструкцією з прийменником de, наприклад civitas Parisiorum > civitas de Parisiis. Значення слова civitas пройшло через метонімію від апелятива cité - місто, la "cité des Parisiens" > la "ville de Paris". Лексема civitas використовується й у значенні «обєднання громадян», це означає, що люди політично організовані в рамках міста-держави cité-état (що було характерним для греко-римської цивілізації) або держави. До того ж цим терміном римляни називали галльське населення, яке мало племінний уклад. Там, де міська цивілізація була ще слаборозвиненою, наприклад у Галлії, римляни заснували міста-центри, столиці місцевих територіальних одиниць. На урбанізованих територіях вони були дуже численними, проте займали незначну територію, хоча могли охоплювати й широку географічну зону (іноді декілька департаментів) ${ }^{51}$.

Керуючись історичним поглядом Каміль Жуліан стверджує, що ця трансформація зумовлена указом Каракаля (édit de Caracalla), який наділяв правами римських громадян усіх жителів Імперії.

На думку А. Доза, зміни були спонтанними і свідчили про глибоке соціальне зрушення. Саме ж велике переселення народів, феодальне

51 Пежинська О.М. Роль історичних факторів у формуванні топонімів (на матеріалі французької мови). Науковий вісник Волинського національного університету імені Лесі Украйнки : серія : Мовознавство. Луцьк, 2010. № 8. C. 217-220. 
рабство, германська колонізація, розвиток сільських центрів, меровінгська династія, розвиток християнства мали значний вплив на звичаї і на політику Франції й особливо на зародження топонімної науки. Як приклад - топонім Amiens (Somme) < гал. міста Ambiens (лат. Ambiani) ${ }^{52}$. Таким же способом мотивувалася назва міста Angers (Maine-et-Loire) < Andécaves та інші топоніми. Етнонім Les Atrébates (< лат. Atrebates) жили у місті Atrebatis > Arras, яке є головним містом в департаменті Pas-de-Calais.

Назва головного міста civitates вживалася із закінченням -is, наприклад, столиця civitas Pictavorum названа Pictavis (Poitiers) ${ }^{53}$, a столиця civitas Rutenorum - Rutenis (Rodez) $)^{54}$, тому у сучасних назвах цих міст майже завжди присутнє закінчення $-s$, яке вказує на називний відмінок, який зберігся у більшості топонімів ${ }^{55}$.

Необхідно зазначити, що назви сучасних міст утворені вже від латинізованих термінів у галло-римську епоху.

Галльські етноніми поступово змінюються назвами первісних міст ще до перетворення їх на civitates (cités) Римської імперії, згодом - на великі сучасні міста: Paris, Metz, Nantes, Rodez, Redon та Rennes, Amiens, Bourges, Troyes.

Окрім галло-римських civitas, баски (Les Basques) залишили після себе назву Gascogne < Guasconia < лат. Wasconia. На відміну від інших провінцій (Бретані чи Нормандіï), назва Gascongne зникла разом із провінцією, яку вона позначала. I все ж вона функціонує у туристичних путівниках для позначення свого історичного центру басків - міста Gers. Цей термін можна знайти також в інших ВН: у назвах вин Côtes de Gascogne та Floc de Gascogne; у складеній гідронімній назві Le golfe de Gascogne - північна частина Атлантичного океану, що межує 3 двома європейськими країнами (Францією - на заході та Іспанією - на півночі); в оронімі Les Landes de Gascogne - природний регіон Франції в гирлі Аквітанського басейну в Атлантичному океані. Він охоплює три департаменти: Жиронда (Gironde), Ланди (Landes) та Лот і Гаронна (Lot-et-Garonne) ${ }^{56}$.

Burdegale та Rotomagus були головними містами невідомих племен (сьогодні це міста Bordeaux та Rouen). Так само збереглися назви Avenches (Aventicum) та Besançon - (Vesontione), сумнів виникає 3

${ }^{52}$ Vial E. Les Noms de villes et de villages. Paris : Belin, 1983. P. 81.

${ }^{53}$ Dauzat A. Dictionnaire etymologique des noms de lieux en France. Ch. Rostaing. Paris : Larousse. Librairie Guenegaud, 1963. P. 538.

${ }^{54}$ Ibid. P. 572.

${ }^{55}$ Rostaing Ch. Les Noms de lieux. 7 ed. Paris : Presses Universitaires de France, 1969. P. 46-49.

${ }^{56}$ Landes de Gascogne. URL: http://fr.wikipedia.org/wiki/Landes_de_Gascogne 
приводу назви Toul (Tullum) та Strasbourg < straza, route + burg, forteresse (колишня назва якого Argentoraton зберігалася до германської колонізаціi $)^{57}$.

Субституиія проявила себе у середньовіччі щодо назв ClermontFerrand та Saint-Paulien, які до цього називалися Arvernis та Vellavis, а первісно - Augustonemetum та Ruessium.

У Гасконі (Gascogne) та в піренейському регіоні, де традиції племен не були достатньо міцними, головні міста зберегли свою початкову назву, трактування якої є доволі складним, наприклад, Aire (Atura); Arreau (Arrevum; les Arrevasci); Céret (Ceretum; les Ceretani); Eauze (Elusa; les Elusates); Lectoure (Lactora; les Lactorates); Orolon $(\text { Ilurone })^{58}$.

Вторгнення германських племен значно модифікували назви країн:

La Bretagne > Angleterre (la Terre-land- des Angles), l'Armorique > la Bretagne, la Gaule > la France. Окрім цього, бретонські племена залишили помітний слід і у французьких топонімах : Bretteville (в Нормандіi), Brétigny, Brétignolles, Brethenay, Bretonneux та інші.

Визначено 38 сучасних французьких міст, в основі яких містяться галльські етноніми.

\section{ВИСНОВКИ}

Визначено, що особливу роль у творенні топонімів відіграють імена засновників (або власників) споруд та/або означення, що виражають якісну характеристику. Найпоширенішим є термін château < лат. castellum < castrum), задіяний у складних та складених назвах 3 переважанням народних форм. Терміни -villa та -court входять до складу нових топонімних утворень періоду германського вторгнення. Досліджувані терміни диференціюються у складених конструкціях: додаток + означуване (з компонентом -villa); означуване + додаток та навпаки (з компонентом -court) у сполученні 3 германськими антропонімами та 3 прикметниками.

Аналіз матеріалів показав, що топоніми, в основі яких лежать релігійний компонент (здебільшого назви культових споруд), набули поширення в середні віки, особливо у франкський та феодальний періоди. Топоніми з такими елементами поширені по всій території Франції.

${ }^{57}$ Dauzat A. Dictionnaire etymologique des noms de lieux en France. Ch. Rostaing. Paris : Larousse. Librairie Guenegaud, 1963. P. 665.

${ }^{58}$ Coste J. Dictionnaire des noms propres : Toponymes et patronymes de France. Paris : Armand Colin, 2006. P. 124. 
Поява відантропонімних топонімів пояснюється їх приналежністю певній особі. Латинські та галло-римські антропоніми широко представлені у топонімії (галл. імя + лат. суфікс -асит або -іасит: Ambarriacum>Ambérieu). Спостерігається зміна цього суфікса, залежно від регіону.

Biдепонімні найменування мало представлені. Найпоширенішими 3 них $є$ похідні від імені бога Меркурія (лат. Mercurius): варіанти Merсо̆riu(m), Mercŏre $>$ Mercoeur.

Виявлено 752 випадки вживання топонімів із компонентом dominus. Найважливішими особливостями топонімів із компонентом saint $\epsilon$ значне географічне поширення цих назв та різноманітність їх діалектних форм. Визначено 38 сучасних французьких міст, основу яких становлять галльські етноніми.

\section{АНОТАЦІЯ}

У межах групи назв, похідних від антропонімів, привертають увагу насамперед ті, що утворені від власних імен осіб, а також похідні від загальних назв осіб (назви племінно-етнічних груп або вихідців з інших місць). Значна кількість відантропонімних топонімів зумовлена передусім тим, що географічні об'єкти зазвичай комусь належали, звідси - географічні назви, утворені від імен власників.

Водночас лінгвістичний аналіз відантропонімних онімів Франції свідчить, що чимало вживаних тут християнських імен за своїм походженням є запозиченнями (йдеться про місце їх виникнення). Відантропонімні топоніми мотивуються:

1) іменами власників територій,

2) епонімами (назвами божеств),

3) іменами святих (hagiotoponymes),

4) родоплемінними іменами та назвами різних народів (відетнонімні найменування).

Виявлено 752 випадки вживання топонімів із компонентом dominus. Найважливішими особливостями топонімів із компонентом saint $\epsilon$ значне географічне поширення цих назв та різноманітність їх діалектних форм. Визначено 38 сучасних французьких міст, основу яких становлять галльські етноніми.

\section{ЛIТЕРАТУРА}

1. Пежинська O.M. Компонент Saint та його роль в утворенні складних топонімних назв у старофранцузькій мові. Вісник Львівського університету : серія «Іноземні мови». 2009. Вип. 16. С. 84-92.

2. Пежинська О.М. Роль історичних факторів у формуванні топонімів (на матеріалі французької мови). Науковий вісник 
Волинського національного університету імені Лесі Украӥнки : серія : Мовознавство. Луцьк, 2010. № 8. С. 217-220.

3. Суперанская А.В. Что такое топонимика? Москва : Наука, 1985. $176 \mathrm{c}$.

4. Brunhes J. Géographie humaine de la France. Paris, 1921. T. I. 299 p.

5. Coste J. Dictionnaire des noms propres : Toponymes et patronymes de France. Paris : Armand Colin, 2006. 700 p.

6. Dauzat A. Dictionnaire étymologique des noms de lieux en France. Ch. Rostaing. Paris : Larousse. Librairie Guénégaud, 1963. 738 p.

7. Dauzat A. Les noms de lieux. Origine et évolution. Paris : Librairie delagrave, 1926. 264 p.

8. Fabre P. Noms de lieux du Languedoc. Paris : Bonneton, 1995. 243 p.

9. Joanne P. Dictionnaire géographique et administratif de la France et de ses colonies. Paris : Librairie Hachette, 1890-1905. URL: http://gallica.bnf.fr/ark:/12148/bpt6k73390r/f671.image.r.

10. Landes de Gascogne. URL: http://fr.wikipedia.org/wiki/Landes_ de_Gascogne.

11. Lejeune S. La religion dans la toponymie. Festival International de Géographie 2002 Saint-Dié-des-Vosges "Les espaces et les lieux du religieux". URL: http://fig-st-die.education.fr/actes/actes_2002/index.htm.

12. Longnon A. Les noms de lieu de la France : leur origine, leur signification. Paris : Language, Arts \& Disciplines, 1973. 831 p.

13. Rostaing Ch. Les Noms de lieux. 7 éd. Paris : Presses Universitaires de France, 1969. 224 p.

14. Vial É. Les Noms de villes et de villages. Paris : Belin, 1983. 319 p.

\section{Information about the author:} Pezhynska O. M.,

Candidate of Philological Sciences, Associate Professor at the Department of Romano-Germanic Languages Ternopil Volodymyr Hnatiuk National Pedagogical University 2, Kryvonosa str., Ternopil, 46027, Ukraine 